\title{
In vitro anthelmintic activity of an aqueous extract of Glycyrrhiza glabra and of glycyrrhetinic acid against gastrointestinal nematodes of small ruminants
}

\author{
Michela Maestrini $^{1}$ (D), Marcelo Beltrão Molento $^{2}$ (D), Mario Forzan ${ }^{1}$ (D), and Stefania Perrucci ${ }^{1, *}$ (D) \\ ${ }^{1}$ Department of Veterinary Sciences, University of Pisa, Viale delle Piagge 2, 56124 Pisa, Italy \\ ${ }^{2}$ Department of Veterinary Medicine, University of Paraná, R. dos Funcionarios, 1540, Curitiba, 80035-050 PR, Brazil
}

Received 14 December 2020, Accepted 12 August 2021, Published online 1 September 2021

\begin{abstract}
This study evaluated the in vitro anthelmintic activity of a liquorice (Glycyrrhiza glabra) root aqueous extract and of glycyrrhetinic acid at 30,10,5,1, and $0.5 \mathrm{mg} / \mathrm{mL}$ against sheep gastrointestinal nematodes (GINs), using the egg hatch test (EHT), the larval development test (LDT), and the larval migration inhibition test (LMIT). The compounds were applied on a mixture of GIN eggs and larvae, mainly Trichostrongylus spp. and Teladorsagia/Ostertagia spp. Cytotoxicity assays were also performed. In the EHT, both candidates showed significant concentration-dependent efficacy and were significantly more effective $(p<0.001)$ at the highest concentrations $(30$ and $10 \mathrm{mg} / \mathrm{mL})$ than the lowest ones. In the LDT, only G. glabra showed a concentration-dependent effect $\left(R^{2}=0.924\right)$, but glycyrrhetinic acid $\left(R^{2}=0.910\right)$ had significantly higher efficacy than G. glabra root extract. Moreover, the efficacy of glycyrrhetinic acid at 30,10 , and $5 \mathrm{mg} / \mathrm{mL}$ was significantly higher $(p<0.001)$ than at lower concentrations. In the LMIT, G. glabra showed concentration-dependent efficacy $\left(R^{2}=0.971\right)$, while considerably reduced efficacy was observed for glycyrrhetinic acid $\left(R^{2}=0.855\right)$ at the lowest concentrations. These data suggest that the two compounds may have different mechanisms of action. In the LMIT, the $50 \%$ lethal concentration $\left(\mathrm{LC}_{50}\right)$ of glycyrrhetinic acid $(\sim 5.12 \mathrm{mg} / \mathrm{mL})$ was $>2.0$-fold lower when compared to G. glabra $(12.25 \mathrm{mg} / \mathrm{mL})$. Analysis and previous findings indicated low toxicity for both compounds. The results obtained encourage in vivo studies aimed at evaluating the potential use of the tested compounds as natural de-wormers in ruminants.
\end{abstract}

Key words: Glycyrrhiza glabra, Glycyrrhetinic acid, Gastrointestinal strongyles, Sheep, Anthelmintic activity, In vitro.

Résumé - Activité anthelminthique in vitro d'un extrait aqueux de Glycyrrhiza glabra et de l'acide glycyrrhétinique contre les nématodes gastro-intestinaux des petits ruminants. Cette étude a évalué l'activité anthelminthique in vitro d'un extrait aqueux de racine de réglisse (Glycyrrhiza glabra) et de l'acide glycyrrhétinique à 30 , $10,5,1$ et $0,5 \mathrm{mg} / \mathrm{mL}$ contre les nématodes gastro-intestinaux (NGI) du mouton, en utilisant le test d'éclosion des œufs (TEO), le test de développement larvaire (TDL) et le test d'inhibition de la migration larvaire (TIML). Les composés ont été appliqués sur un mélange d'œufs et de larves de NGI, principalement Trichostrongylus spp. et Teladorsagia/ Ostertagia spp. Des tests de cytotoxicité ont également été effectués. Dans le TEO, les deux candidats ont montré une efficacité concentration-dépendante significative et ont été significativement plus efficaces $(p<0,001)$ aux concentrations les plus élevées (30 et $10 \mathrm{mg} / \mathrm{mL}$ ) qu'aux plus faibles. Dans le TDL, seul G. glabra a montré un effet concentrationdépendant $\left(R^{2}=0,924\right)$, mais l'acide glycyrrhétinique $\left(R^{2}=0,910\right)$ avait une efficacité significativement plus élevée que l'extrait de racine de G. glabra. De plus, l'efficacité de l'acide glycyrrhétinique à 30,10 et $5 \mathrm{mg} / \mathrm{mL}$ était significativement plus élevée $(P<0,001)$ qu'à des concentrations plus faibles. Dans le TIML, G. glabra a montré une efficacité concentration-dépendante $\left(R^{2}=0,971\right)$, tandis qu'une forte réduction d'efficacité a été observée pour l'acide glycyrrhétinique $\left(R^{2}=0,855\right)$ aux concentrations les plus faibles. Ces données peuvent suggérer que les deux composés peuvent avoir des mécanismes d'action différents. Dans le TIML, la concentration létale à $50 \%$ (CL50) de l'acide glycyrrhétinique $(\sim 5,12 \mathrm{mg} / \mathrm{mL})$ était $>2,0$ fois inférieure à celle de G. glabra $(12,25 \mathrm{mg} / \mathrm{mL})$. L'analyse et les résultats précédents ont indiqué une faible toxicité pour les deux composés. Les résultats obtenus encouragent les études in vivo visant à évaluer l'utilisation potentielle des composés testés ici comme anthelminthique naturels chez les ruminants.

\footnotetext{
*Corresponding author: stefania.perrucci@unipi.it 


\section{Introduction}

Infections caused by gastrointestinal nematodes (GIN) are considered one of the main causes of production losses, health problems, and poor welfare in small ruminants worldwide [51]. For more than 50 years, the control of GIN infections in livestock has relied mainly on the use of synthetic anthelmintic drugs [42]. However, in recent years a drastic reduction of the effectiveness of these drugs has been observed, caused by the selection of anthelmintic-resistant parasite populations, especially in sheep and goats [24, 43]. In Europe, a further limitation to the use of anthelmintic drugs for the control of GIN is linked to organic breeding, in which the use of synthetic drugs is limited by European regulations [13, 14].

Currently, the search for alternative control methods of ovine GIN is considered an important and urgent issue [37, 50, 51]. Among these alternative strategies, there is considerable and expanding interest in the search for effective plant extracts and plant-derived active components, namely plant secondary metabolites [5, 37]. The latter include mainly tannins, terpenoids, saponins, and flavonoids, as these components have been related to effective responses in vitro and/or in vivo against GINs of small ruminants (i.e., Haemonchus spp., and Trichostrongylus spp.) in different countries [18, 19, 28, 33, 34, 36, 44, 45].

Previous studies have shown promising in vitro antiparasitic properties of plant species belonging to the genus Glycyrrhiza. The genus Glycyrrhiza (Fabaceae) consists of about 30 plant species, including the species Glycyrrhiza glabra and Glycyrrhiza inflata [41]. The crude extract of G. inflata roots, also known as Chinese liquorice [38, 39], was found to be effective against the promastigote and amastigote stages of Leishmania spp. [39]. Another interesting study carried out by Aleixo et al. [1], has demonstrated the ability of $G$. inflata to alter cell integrity causing the death of Schistosoma mansoni, also affecting its motility and fertility. Moreover, the anthelmintic activity of an ethanolic extract and, albeit with lower efficacy, also of an aqueous rhizome extract of G. glabra have demonstrated in vitro activity against adults of Haemonchus contortus collected from the abomasum of infected sheep, using a micro-motility assay [29].

Glycyrrhiza glabra is a flowering plant commonly known as liquorice, native to Mediterranean areas, but now present in India, Russia, and China [41]. Glycyrrhetinic acid, also known as 18 $\beta$-glycyrrhetinic acid, glycyrrhetic acid or enoxolone, is a pentacyclic triterpenic organic acid considered to be the major active component of G. glabra root aqueous extract. Glycyrrhiza glabra root may contain 2 to $25 \%$ glycyrrhetinic acid, mainly as glycosidic glycyrrhizinic acid saponin [20], along with other compounds such as polyphenols, saponins, and triterpenes [20, 40]. Limited anthelmintic potential of glycyrrhetinic acid was assessed in a study by Kalani et al. [27], where the authors have shown that this compound and some of its synthetic derivatives were effective in vitro against microfilariae and the adult stage of Brugia malayi.

The aim of the present study was to evaluate the in vitro activity of an aqueous extract of G. glabra root and of glycyrrhetinic acid against GINs of small ruminants.

\section{Materials and methods Plant materials}

A commercial lyophilized aqueous extract obtained from the roots of liquorice plant (G. glabra) containing $10 \%$ glycyrrhetinic acid, mainly as glycyrrhizinic acid saponin (EPO Instituto Farmochimico Fitoterapico Srl, Milan, Italy), was diluted in distilled water at the final tested concentrations $(30,10,5,1$, and $0.5 \mathrm{mg} / \mathrm{mL})$. Glycyrrhetinic acid used in this study was a commercial sample (18 $\beta$-glycyrrhetinic acid, Sigma, Italy). Glycyrrhetinic acid was diluted 1:1 (w/v) in a mixture composed by $0.1 \mathrm{~mL}$ of $\mathrm{DMSO} / \mathrm{mL}$ in distilled water, then further diluted at the above tested concentrations.

\section{GIN eggs and third stage larvae (L3) recovery, purification, and identification}

Individual faecal samples were collected from the rectum of naturally infected ewes. Ewes had polyparasitism with different GIN genera and species. Parasitological analysis of the collected samples was performed using a McMaster method, with a sensitivity of 50 eggs per gram (EPG) of faeces [47]. Faecal samples scoring positive for at least 1000 EPG were pooled and used in the assays, and for preparing the faecal cultures to obtain fresh L3. L3 were identified to the genus level. Recovery, suspension, and cultivation of eggs were performed using a previously reported protocol [25], with small modifications. In short, $30 \mathrm{~g}$ faecal material was homogenised in distilled water, placed inside a $50 \mathrm{~mL}$ tube, and centrifuged for $5 \mathrm{~min}$ at $2300 \mathrm{rpm}$. The sediment was collected and suspended in saturated $\mathrm{NaCl}$ solution (specific density 1.2) and centrifuged for another $5 \mathrm{~min}$ at $1000 \mathrm{rpm}$. The supernatant was then collected, diluted in distilled water in $15 \mathrm{~mL}$ tubes and then centrifuged for $5 \mathrm{~min}$ at $800 \mathrm{rpm}$. The sediment containing the eggs was collected and diluted in $1 \mathrm{~mL}$ of distilled water for GIN eggs/mL determination. To obtain L3 from eggs, faecal cultures were performed with pooled positive samples. Copro-cultures were placed in an incubator at $27{ }^{\circ} \mathrm{C}$ from 7 to 10 days. L3 were recovered by the Baermann technique and used in the LMIT. Moreover, about 100 larvae were microscopically identified to the genus level, based on their morphological and metric features [49]. In brief, L3 identification was based on several ensheathed L3 characteristics, including L3 dimensions (length and width), number and shape of intestinal cells, length and shape of the tail, shape of the head, the presence or absence of cranial refractile spots, and length and shape of the oesophagus. The presence or absence of digitate appendages on the tail of exsheathed (2\% hypochlorite- treated) L3 was also evaluated [49].

\section{In vitro tests: egg hatch test (EHT), larval development test (LDT), and larval migration inhibition test (LMIT)}

The EHT was performed according to the method described by Coles et al. [8]. Using 24-well cell culture plates, 100 purified eggs were placed in each well with $1 \mathrm{~mL}$ of a solution containing different concentrations $(30,10,5,1$, and 


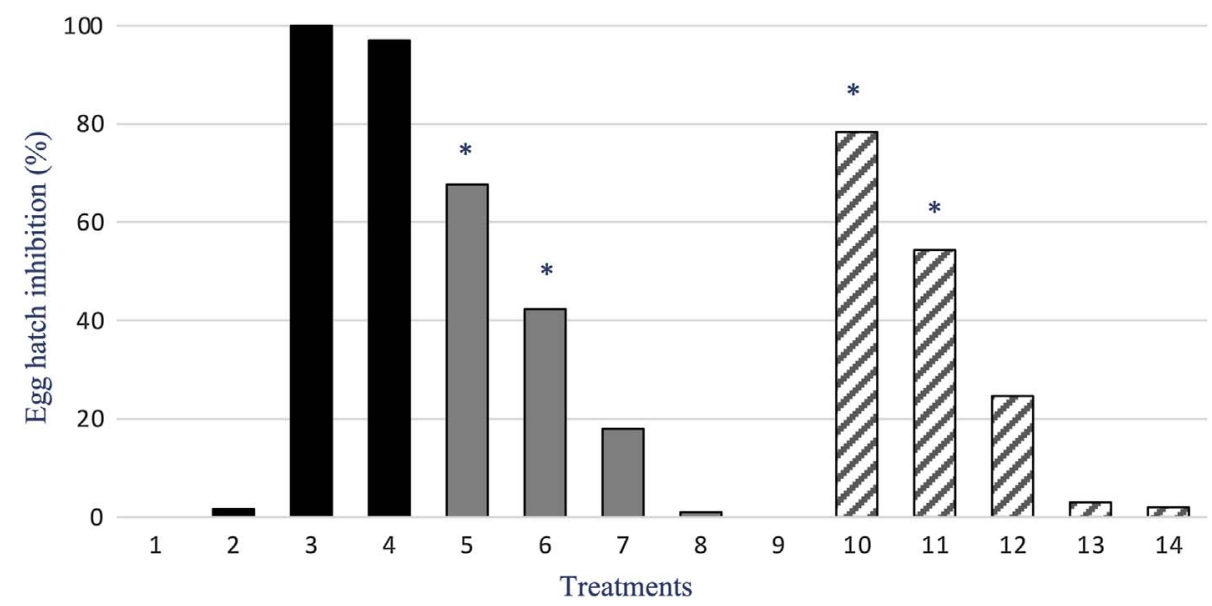

Figure 1. Percentage (\%) of gastrointestinal strongyle egg hatch inhibition by five concentrations of Glycyrrhiza glabra root aqueous extract and of glycyrrhetinic acid. Columns: 1: Untreated, 2: DMSO, 3: Thiabendazole, 4: Thiabendazole plus DMSO, 5: $30 \mathrm{mg} / \mathrm{mL}, 6: 10 \mathrm{mg} / \mathrm{mL}$, 7: $5 \mathrm{mg} / \mathrm{mL}, 8: 1 \mathrm{mg} / \mathrm{mL}$, 9: $0.5 \mathrm{mg} / \mathrm{mL}$ of G. glabra, and 10: $30 \mathrm{mg} / \mathrm{mL}, 11: 10 \mathrm{mg} / \mathrm{mL}, 12: 5 \mathrm{mg} / \mathrm{mL}, 13: 1 \mathrm{mg} / \mathrm{mL}, 14: 0.5 \mathrm{mg} / \mathrm{mL}$ of glycyrrhetinic acid.

$0.5 \mathrm{mg} / \mathrm{mL}$ ) of the tested compounds. Plates were incubated at $26{ }^{\circ} \mathrm{C}$ in darkness and $80 \%$ humidity, checked after $48 \mathrm{~h}$ under an inverted microscope. The number of unhatched and hatched eggs was calculated for each well.

In the LDT, motile L1 obtained from EHT control plates were used by placing about $100 \mathrm{~L} 1 /$ well containing $1 \mathrm{~mL}$ of a solution made with the tested concentrations in the culture medium. Each $\mathrm{mL}$ of the culture medium contained $0.54 \mathrm{~mL}$ of saline solution, $0.06 \mathrm{~mL}$ of Earl Balanced Salt Solution (Escherichia coli lyophilised cells of Strain W) (Sigma Aldrich Srl, Milan, Italy), $12 \mu \mathrm{L}$ of $E$. coli lyophilised and sterilised for $1 \mathrm{~h}$ at $100{ }^{\circ} \mathrm{C}$ (Sigma Aldrich Srl, Milan, Italy), $12 \mu \mathrm{g}$ of amphotericin B (Amphotericin B from Streptomyces approx. $80 \%$ HPLC, Sigma Aldrich, Milan, Italy), $60 \mu \mathrm{g}$ of yeast extract (Sigma Aldrich, Milan, Italy) and $0.24 \mathrm{~mL}$ of distilled water. Plates were incubated at $26{ }^{\circ} \mathrm{C}$ in darkness and $80 \%$ humidity and checked after 7 days under an inverted microscope to evaluate L3 morphology [35, 49]. The percentage of L3 from the total number of larvae was calculated for each well.

The LMIT was based on Demeler et al. [11], with modifications. For the test, about 100 exsheathed (2\% hypochlorite) motile L3 were placed in each well, containing $1 \mathrm{~mL}$ of the tested compounds. Plates with L3 were incubated at $26{ }^{\circ} \mathrm{C}$ in darkness and $80 \%$ humidity, and live L3 were allowed to swing through a $25 \mu \mathrm{m}$ mesh. The meshes were removed after $24 \mathrm{~h}$, and the L3 that had migrated, were present at the bottom of each well. The efficacy of each concentration on L3 was measured according to the formula:

$\mathrm{E}(\%)=($ Total number of L3

- Number of migrated L3/Total number of L3) $\times 100$.

In all assays, the effects of liquorice extract and glycyrrhetinic acid were compared with untreated $(1 \mathrm{~mL}$ of distilled water or $1 \mathrm{~mL}$ of a mixture composed by $0.1 \mathrm{~mL}$ of $\mathrm{DMSO} / \mathrm{mL}$ of distilled water) and treated positive controls $(0.1 \mathrm{mg} / \mathrm{mL}$ thiabendazole (2-(4-Thiazoly) Benzimidazole) (Sigma, Milan, Italy) (TBZ) diluted in distilled water, or in a mixture composed of
$0.1 \mathrm{~mL}$ of $\mathrm{DMSO} / \mathrm{mL}$ in distilled water. All assays were performed in three replicates for each concentration of examined compounds and controls.

\section{Cytotoxicity assay}

The cytotoxicity of $G$. glabra aqueous extract was evaluated on Madin-Darby bovine kidney (MDBK) cells using the Cytotoxicity LDH Assay Kit-WST (Dojindo laboratories, Dojindo EU GmbH, Munich, Germany), following the manufacturer's instructions. This is a commercial kit for the determination of cytotoxicity by measuring lactate dehydrogenase $(\mathrm{LDH})$, which is a cytoplasmic enzyme present in all types of cells and released from damaged cells. LDH catalyses dehydrogenation of lactate to pyruvate reducing NAD to NADH. NADH reduces a water-soluble tetrazolium salt in the presence of an electron mediator to produce an orange formazan dye. The amount of formazan dye is proportional to released LDH into the medium, that is an indication of cytotoxicity. More specifically, cells were plated at $1.5 \times 10^{3} /$ well in 96 well tissue flat bottomed culture plates and incubated at $37^{\circ} \mathrm{C}$ in a $5 \% \mathrm{CO}_{2}$ incubator for $24 \mathrm{~h}$. The cells were washed in Dulbecco's Modified Eagle Medium without phenol red and incubated for $1 \mathrm{~h}$ at $37{ }^{\circ} \mathrm{C}$ in the presence of scalar concentrations (30, 10, 5, 1, and $0.5 \mathrm{mg} / \mathrm{mL})$ of $G$. glabra root. Then, the lysis buffer was added, and the plates incubated again for $30 \mathrm{~min}$ at the same conditions as above. The absorbance was measured at $490 \mathrm{~nm}$ by a microplate reader (ThermoFisher Scientific, Rodano, Milan, Italy).

\section{Statistical analysis}

Descriptive analysis was carried out to demonstrate the compounds' effects. The One-Way Analysis of Variance, ANOVA, and $t$-test were used to determine the differences among concentrations at the 0.05 level, as the data were tested for normality. The coefficient of determination using Pearson $\left(R^{2}\right)$ was calculated for each compound and for each in vitro test. 
The latter test was used to demonstrate the associated fitted efficacy values. The lethal concentration of $50 \%$ (LC50) based on Probit transformation (log-1) was calculated to determine the differences among products in each test, using Prism 7.1 software.

\section{Results}

The results obtained with the EHT are shown in Figure 1. The untreated and the solvent DMSO control groups demonstrated no effect on eggs, and the TBZ and TBZ plus DMSO groups showed efficacies $>98 \%$. Both candidate compounds showed a concentration-dependent anthelmintic effect with an $R^{2}=0.994$ for $G$. glabra and $R^{2}=0.984$ for glycyrrhetinic acid. For the two compounds, the efficacy of the higher concentrations ( 30 and $10 \mathrm{mg} / \mathrm{mL}$ ) was significantly different $(p<0.001)$ from that of the lower concentrations. Glycyrrhetinic acid demonstrated better efficacy against egg development when compared to G. glabra, by an average of $10 \%$. The $\mathrm{LC}_{50}$ was somewhat similar for both candidates (Fig. 2a), as the values were 8.61 and $8.07 \mathrm{mg} / \mathrm{mL}$ for G. glabra and glycyrrhetinic acid, respectively.

The results obtained with the LDT are shown in Figure 3. The untreated and the solvent DMSO control groups showed some small (14-19\%) effects on L1 to L3 development, while TBZ and TBZ plus DMSO showed full efficacy also in this assay. In this test, only G. glabra showed a concentrationdependent effect with an $R^{2}=0.924$. However, glycyrrhetinic acid had $R^{2}=0.910$ with $64 \%$ efficacy also at lower concentrations. For G. glabra, the efficacy of the highest concentration $(30 \mathrm{mg} / \mathrm{mL})$ was significantly higher $(p<0.001)$ from that of all other concentrations. As for glycyrrhetinic acid, the efficacy of the three highest concentrations was significantly higher $(p<0.001)$ than that of the two lowest concentrations. Glycyrrhetinic acid showed significantly higher efficacy against L3 development when compared to G. glabra, by an average of $30 \%$. For the LDT, the $\mathrm{LC}_{50}$ observed for glycyrrhetinic acid $(5.10 \mathrm{mg} / \mathrm{mL})$ was 2.7 -fold lower, when compared to that of G. glabra (13.67 mg/mL) (Fig. 2b).

The data obtained in the LMIT are shown in Figure 4. The untreated and the solvent DMSO control groups showed only some small (1-7\%) effects on L3 migration, while TBZ and TBZ plus DMSO had efficacies > 95\%. Glycyrrhiza glabra showed a clear concentration-dependent effect with $R^{2}=0.971$, while glycyrrhetinic acid had $R^{2}=0.855$, with a drastic reduction of efficacy at lower concentrations. For G. glabra, the efficacy of the highest concentration $(30 \mathrm{mg} / \mathrm{mL})$ was significantly different $(p<0.001)$ with respect to all other concentrations. The efficacy of glycyrrhetinic acid at the three highest concentrations was significantly different $(p<0.001)$ from that of the two lowest concentrations. Moreover, glycyrrhetinic acid showed efficacy against L3 development $>400 \%$ higher on average when compared to that of G. glabra. For the LMIT, the $\mathrm{LC}_{50}$ of glycyrrhetinic acid $(\sim 5.12 \mathrm{mg} / \mathrm{mL})$ was $>2.0$-fold lower when compared to that of G. glabra $(12.25 \mathrm{mg} / \mathrm{mL})$ (Fig. 2c).

Concerning the cytotoxicity assay, results indicated a dosedependent effect and low toxicity of G. glabra root extract.
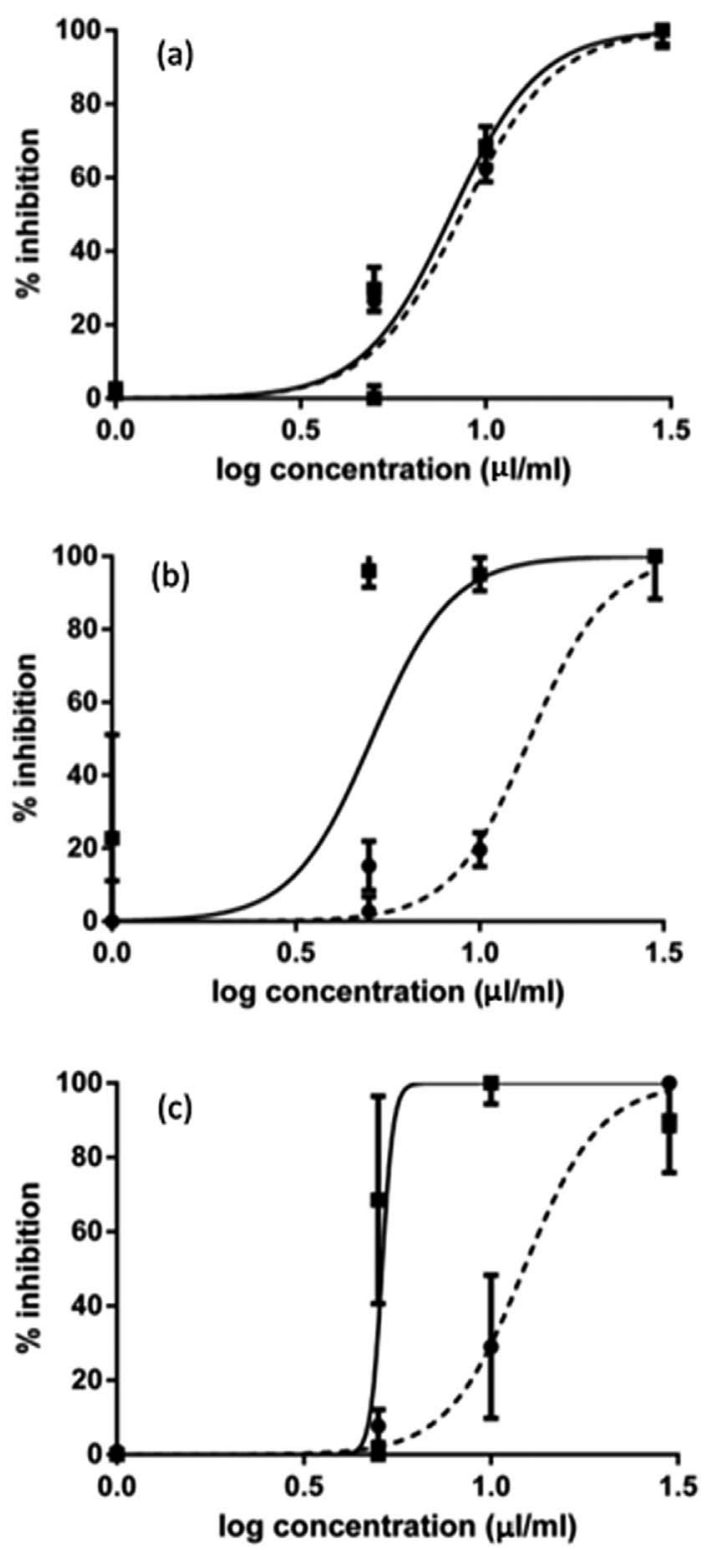

Figure 2. Efficacy (\%) of different concentrations (log-1) $(\mathrm{mg} / \mathrm{mL})$ of Glycyrrhiza glabra root aqueous extract (dashed line) and of glycyrrhetinic acid (solid line) for the (a) egg hatch test (EHT), (b) > larval development test (LDT), and (c) larval migration inhibition test (LMIT) against gastrointestinal strongyles of sheep.

More specifically, $23.5 \%, 5.4 \%, 2.3 \%, 0.16 \%$ and $0.08 \%$ cytotoxicity were observed for $30,10,5,1$, and $0.5 \mathrm{mg} / \mathrm{mL}$ of the extract, respectively.

L3 identification showed that Trichostrongylus spp. (39.7\%), Teladorsagia/Ostertagia spp. (19.2\%), Cooperia spp. (14.3\%), Chabertia ovina (7.4\%), Oesophagostomum spp. (6.8\%), Bunostomum spp. (1.8\%), Haemonchus spp. (1\%), and Strongyloides papillosus larvae $(9.8 \%)$ were present in faecal pools used in the assays. Differential identification and counting of Teladorsagia spp. and Trichostrongylus spp. were performed based on morphology of ensheathed and exsheathed L3 according to the method reported by van Wyk and Mayhew [49]. The L3 of S. papillosus were distinguished from those of gastrointestinal strongyles based on their smaller width, 


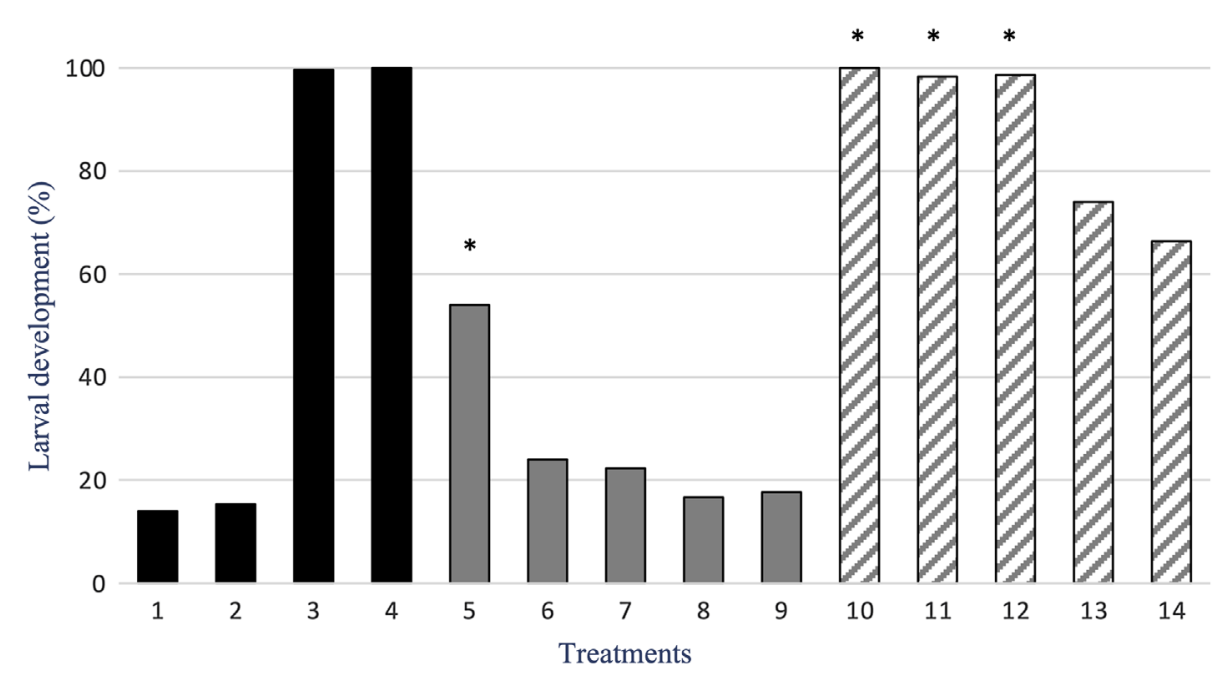

Figure 3. Percentage $(\%)$ of inhibition of gastrointestinal strongyle larval development by five concentrations of Glycyrrhiza glabra aqueous extract and of glycyrrhetinic acid. Columns: 1: Untreated, 2: DMSO, 3: Thiabendazole, 4: Thiabendazole plus DMSO, 5: $30 \mathrm{mg} / \mathrm{mL}$, 6: $10 \mathrm{mg} / \mathrm{mL}, 7: 5 \mathrm{mg} / \mathrm{mL}, 8: 1 \mathrm{mg} / \mathrm{mL}, 9: 0.5 \mathrm{mg} / \mathrm{mL}$ of G. glabra, and $10: 30 \mathrm{mg} / \mathrm{mL}, 11: 10 \mathrm{mg} / \mathrm{mL}, 12: 5 \mathrm{mg} / \mathrm{mL}, 13: 1 \mathrm{mg} / \mathrm{mL}$, 14: $0.5 \mathrm{mg} / \mathrm{mL}$ of glycyrrhetinic acid.

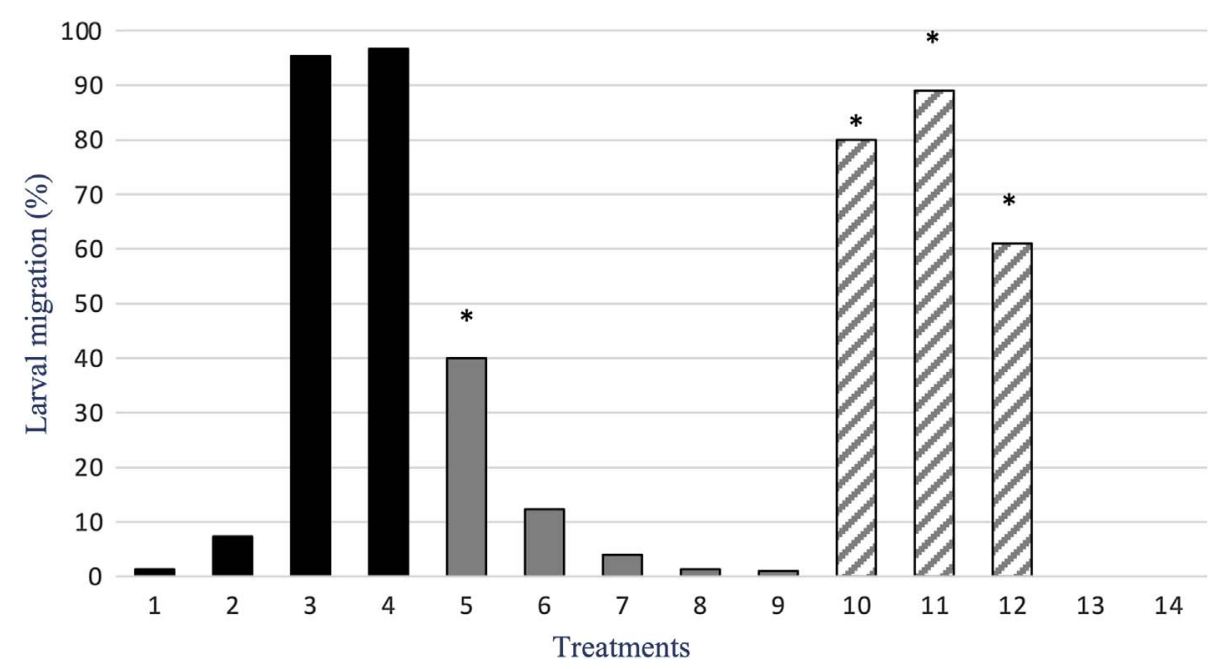

Figure 4. Percentage (\%) of inhibition of gastrointestinal strongyle larval migration by five concentrations of Glycyrrhiza glabra aqueous extract and of glycyrrhetinic acid. Columns 1: Untreated, 2: DMSO, 3: Thiabendazole, 4: Thiabendazole plus DMSO, 5: $30 \mathrm{mg} / \mathrm{mL}$, 6: $10 \mathrm{mg} / \mathrm{mL}, 7: 5 \mathrm{mg} / \mathrm{mL}, 8: 1 \mathrm{mg} / \mathrm{mL}, 9: 0.5 \mathrm{mg} / \mathrm{mL}$ of G. glabra, and 10: $30 \mathrm{mg} / \mathrm{mL}, 11: 10 \mathrm{mg} / \mathrm{mL}, 12: 5 \mathrm{mg} / \mathrm{mL}, 13: 1 \mathrm{mg} / \mathrm{mL}$, 14: $0.5 \mathrm{mg} / \mathrm{mL}$ of glycyrrhetinic acid.

oesophagus length (about $40 \%$ of the total body length), the bifid tip of the tail and the absence of sheath tail extension [49]. Nematodirus spp. eggs were not found at faecal microscopical examination.

\section{Discussion}

The present study evaluated the in vitro ability of an aqueous extract of G. glabra roots containing $10 \%$ glycyrrhetinic acid (mainly as glycyrrhizinic acid saponin) and of pure glycyrrhetinic acid, against free-living stages (eggs and larvae) of a mixture of sheep GINs found in naturally infected sheep. Considering that on sheep farms it is unlikely that GIN infections are caused by a single nematode genus/species, in the in vitro assays we decided to use faecal samples collected from sheep naturally infected by different genera/species. However, this choice may also represent a limitation of the study since the in vitro anthelmintic activity of the two compounds examined here cannot be targeted to a specific sheep gastrointestinal nematode species. Nevertheless, considering that in the faecal samples used in this study most of these nematodes were found to belong to the genera Trichostrongylus, Teladorsagial Ostertagia and Cooperia, which represented about the $75 \%$ of the totality of identified larvae, it can be assumed that the anthelmintic effects observed for G. glabra extract and glycyrrhetinic acid should be attributed at least to these genera.

Glycyrrhiza spp. plants, mainly G. glabra, glycyrrhizinic acid and glycyrrhetinic acid show several pharmacological properties in vitro, and in some case also in vivo, including 
antiviral (including HIV, SARS-Coronavirus, Hepatitis B, and $\mathrm{C}$ viruses, influenza $\mathrm{A}$ virus, porcine reproductive and respiratory syndrome virus, and rotavirus), antibacterial (Bacillus subtilis, Staphylococcus aureus, S. epidermis, E. coli, Pseudomonas aeruginosa, Mycobacterium bovis, Helicobacter pylori), antifungal (Candida albicans), and antiprotozoal (Plasmodium falciparum, Leishmania donovani) activities [3, 6, 7, 15-17, 21, 23, 30, 31, 38-41]. Moreover, the anthelmintic activity against $B$. malayi, $S$. mansoni, and $H$. contortus has also been demonstrated in previous studies $[1,27,29]$. For all these properties, glycyrrhizinic acid and glycyrrhetinic acid are considered scaffold molecules for the design and development of new bioactive compounds [20, 30].

In this study, both $G$. glabra root aqueous extract and glycyrrhetinic acid were found to be highly active when used against eggs (EHT), with a marked concentration-dependent effect. However, especially in the LDT and the LMIT, glycyrrhetinic acid showed significantly higher efficacy against sheep GINs compared to that of the plant extract. In LDT, glycyrrhetinic acid was found to be highly effective also at its lowest concentrations. Moreover, in the LDT and the LMIT, the anthelmintic activity of glycyrrhetinic acid at the highest concentration was comparable to that of TBZ. These results were also confirmed by the LC50 found for these two compounds in the different in vitro assays. In fact, while in the EHT similar LC50 values were observed for both candidates, in the LDT and LMIT, the LC50 of glycyrrhetinic acid was more than two fold lower than that of G. glabra extract. On the other hand, in this study the liquorice aqueous extract also showed valuable anthelmintic properties in vitro against GINs of sheep. In fact, the highest concentration of G. glabra extract $(30 \mathrm{mg} / \mathrm{mL})$ was able to significantly inhibit $(>60 \%)$ the hatch of eggs and larval development from L1 to L3 of these nematodes when compared to the untreated controls, while its efficacy against L3 was lower.

These findings confirm, at least partially, the in vitro anthelmintic efficacy reported for the aqueous extract of G. glabra rhizome against adults of the sheep gastric nematode species $H$. contortus [29]. Although G. glabra aqueous extract tested in this study was obtained from the root of this plant, in vitro anthelmintic properties of $G$. glabra aqueous extract was found here also on eggs and larvae of sheep gastrointestinal nematodes. Obtained results also confirm the anthelmintic properties on sheep gastrointestinal nematodes previously reported for glycyrrhetinic acid on B. malayi microfilariae [27]. However, data from the evaluation of the Pearson coefficient suggest that the two compounds may have different mechanisms of action.

Glycyrrhetinic acid is considered the major active component of G. glabra root extract, which may contain about 2-25\% glycyrrhetinic acid, both as such and as the glycosidic glycyrrhizinic acid saponin [23]. In humans, it is in fact known that after oral administration, glycyrrhizinic acid is hydrolysed to glycyrrhetinic acid mainly by the intestinal bacteria $\beta$-D-glucuronidase $[20,40]$. Therefore, results obtained in this study suggest that the anthelmintic activity of G. glabra aqueous extract may rely mainly on its content in glycyrrhizinic acid/glycyrrhetinic acid, as the effect of the pure compound glycyrrhetinic acid was significantly higher than that of the extract. However, the possibility that other components normally present in the G. glabra aqueous extract, such as flavonoids, phytosterols and tannins [26], may also have contributed to its anthelmintic efficacy cannot be definitively ruled out.

Among the activities of glycyrrhetinic acid, this compound is proposed to strengthen enterocyte membrane integrity against both oxidative and proteolytic damage [2, 16, 41, 52]. Considering these protective properties on the intestinal epithelium and considering also that the production of glycyrrhetinic acid occur mainly in the intestine, it is possible to assume that in vivo experiments would demonstrate the potential anthelmintic activity and the beneficial effects on the gut of glycyrrhetinic acid, probably acting mostly on the GIN species infecting the intestinal tract of ruminants. On the other hand, it is also plausible to assume that glycyrrhizinic acid could act also on abomasal GIN species, like T. axei, Teladorsagia spp. and $H$. contortus. Therefore, further in vivo investigations on gastrointestinal strongyle-infected ruminants should include the evaluation of the anthelmintic efficacy of both glycyrrhizinic and glycyrrhetinic acids. Nevertheless, studies have found that GIN infection may alter gut function also by inducing considerable changes in the gut microbiome, for example in the case of GIN infecting the abomasum. This mechanism would involve lowering the acidic environment that functions as a potent barrier limiting the presence and growth of most bacteria [32]. These modifications can also result in several abomasal diseases in ruminants, frequently caused by Clostridium spp., a bacterial genus known to produce $\beta$-D-glucuronidase and that thus may be able to hydrolyse glycyrrhizinic acid contained in the G. glabra aqueous extract into glycyrrhetinic acid [48]. Although pharmacokinetic data for glycyrrhetinic acid in ruminants are not available, in rats the time for this compound to reach maximum plasma concentration is high and this implies slow intestinal absorption, probably also due to the slow conversion of glycyrrhizic acid to glycyrrhetinic acid in the intestine [53]. Moreover, glycyrrhizic acid shows positive pharmacokinetic properties in view of a possible use as an anthelmintic for the treatment of ruminants infected by gastrointestinal nematodes. In fact, although its maximum plasma concentration in rats is within five hours, this compound shows a reabsorption phenomenon by hepato-enteral circulation [53].

Concerning the toxicity of these compounds, results from this study and previous reported data seem to indicate that G. glabra aqueous root extract used in this study, glycyrrhizic and glycyrrhetinic acids may show low toxic effects. In fact, when used as a flavouring in food, glycyrrhizic acid at $1 \mathrm{mg} / \mathrm{kg}$ of complete feed is considered safe in all domestic animal species, including ruminants [12]. In humans, $100-200 \mathrm{mg} /$ day is the upper limit considered safe for ingestion of glycyrrhizin, that correspond to less than $150 \mathrm{gr}$ of liquorice (G. glabra) [20]. Moreover, results of the assay performed in this study showed low cytotoxicity for G. glabra aqueous root extract, as from $76.5 \%$ to about $100 \%$ cell viability was observed in ruminant cell lines following the treatment with the same concentrations $(30,10,5,1$, and $0.5 \mathrm{mg} / \mathrm{mL})$ tested in this study for evaluating the in vitro anthelmintic properties of the extract. Although glycyrrhetinic acid may block gap junction intracellular communication in a dose-dependent manner in animal and human cells, it is considered cytotoxic 
only at high concentrations, with cell viabilities from about $40-80 \%$ to over $90 \%$ observed in different human and animal tumoral cell lines treated with different concentrations of this compound [9, 10, 46]. Moreover, glycyrrhetinic acid and glycyrrhizic acid have anti-inflammatory effects in rats and mice and protect liver tissues [10]. Interestingly, liquorice ethanolic extract supplementation in the diet at $4.5 \%$ of dry matter was demonstrated to have a limited impact on sheep rumen function and improved sheep blood immunoglobulin level and anti-oxidative status [22]. In addition, like other saponins, glycyrrhizic acid has been considered able to modulate rumen bacteria, specifically to inhibit the growth of acetateproducing bacteria and to reduce the population of rumen protozoa. In sheep, these abilities have been associated with positive effects on the ruminal concentrations of total volatile fatty acids, acetate, propionate, and butyrate [22]. Moreover, a positive role of dietary G. glabra root supplementation on chemical and physical properties of cow milk and cheeses has recently been reported [4], as G. glabra root supplementation was found to be able to reduce lipid oxidation and induce positive changes in the colour and flavour of cow cheese.

In conclusion, G. glabra root aqueous extract and glycyrrhetinic acid showed favourable anthelmintic properties on GINs of sheep in all in vitro tests, although glycyrrhetinic acid was more effective than G. glabra root aqueous extract. However, G. glabra root aqueous extract showed low toxicity on ruminant cell lines when used at high concentrations. Further studies aimed at evaluating the in vivo efficacy of the liquorice (G. glabra) aqueous extract used in this study and of glycyrrhetinic acid as ecofriendly antiparasiticides on naturally infected sheep are encouraged.

Acknowledgements. The authors wish to thank the COMBAR COST Action 16230 for giving us the opportunity to participate in this interesting and stimulating project and Dr. Hervé Hoste for his valuable and kind input to this manuscript. The authors also thank EPO, Instituto Farmochimico Fitoterapico Srl, Milan, Italy, for providing the liquorice extract tested in this study and Matteo Mattellini, Gianluca Fichi and Guido Flamini for their technical assistance. The authors declare that there are no competing interests.

\section{References}

1. Aleixo de Carvalho L-S, Geraldo R-B, De Moraes J, Silva Pinto P-L, de Faria Pinto P, dos Santos Pereira O-J, Da Silva Filho A-A. 2015. Schistosomicidal activity and docking of Schistosoma mansoni ATPDase 1 with licoflavone B isolated from Glycyrrhiza inflata (Fabaceae). Experimental Parasitology, 159, 207-214.

2. Asl M-N, Hosseinzadeh H. 2008. Review of pharmacological effects of Glycyrrhiza sp. and its bioactive compounds. Phytotherapy Research, 22, 709-724.

3. Badam L, Amagaya S, Pollard B. 1997. In vitro activity of liquorice and glycyrrhetinic acid on Japanese encephalitis virus. Journal of Community Diseases, 29, 91-99.

4. Bennato F, Ianni A, Innosa D, Martino C, Grotta L, Pomilio F, Verna M, Martino G. 2019. Influence of licorice root feeding on chemical-nutritional quality of cow milk and stracciata cheese, an Italian traditional fresh dairy product. Animals, 9(12), 1153.

5. Bortoluzzi B-B, Buzatti A, Chaaban A, Pritsch I-C, Dos Anjos A, Cipriano R-R, Deschamps C, Molento M-B. 2020. Mentha villosa Hubs., M. $x$ piperita and their bioactives against gastrointestinal nematodes of ruminants and the potential as drug enhancers. Veterinary Parasitology, 289, 109317.

6. Carruthers N-J, McClellan S-A, Somayajulu M, Pitchaikannu A, Bessert D, Peng X, Huitsing K, Stemmer P-M, Hazlett L-D. 2020. Effects of glycyrrhizin on multi-drug resistant Pseudomonas aeruginosa. Pathogens, 9, 766.

7. Cinatl J, Morgenstern B, Bauer G, Chandra P, Rabenau H, Doerr H-W. 2003. Glycyrrhizin, an active component of liquorice roots, and replication of SARS-associated coronavirus. Lancet, 361, 2045-2046.

8. Coles G-C, Jackson F, Pomroy W-E, Prichard R-K, von SamsonHimmelstjerna G, Silvestre A, Taylor M-A, Vercruysse J. 2006. The detection of anthelmintic resistance in nematodes of veterinary importance. Veterinary Parasitology, 136, 167-185.

9. Cong Y, Shi B, Lu Y, Wen S, Chung R, Jin D. 2016. One-step conjugation of glycyrrhetinic acid to cationic polymers for highperformance gene delivery to cultured liver cell. Scientific Reports, 6, 21891.

10. Cosmetic Ingredient Review Expert Panel. 2007. Final report on the safety assessment of glycyrrhetinic acid, potassium glycyrrhetinate, disodium succinoyl glycyrrhetinate, glyceryl glycyrrhetinate, glycyrrhetinyl stearate, stearyl glycyrrhetinate, glycyrrhizic acid, ammonium glycyrrhizate, dipotassium glycyrrhizate, disodium glycyrrhizate, trisodium glycyrrhizate, methyl glycyrrhizate, and potassium glycyrrhizinate. International Journal of Toxicology, 26, 79-112.

11. Demeler J, Küttler U, El-Abdellati A, Stafford K, Rydzik A, Varady M, Kenyon F, Coles G, Höglund J, Jackson F, Vercruysse J, von Samson-Himmelstjerna G. 2010. Standardization of the larval migration inhibition test for the detection of resistance to ivermectin in gastrointestinal nematodes of ruminants. Veterinary Parasitology, 174, 58-64.

12. European Food Safety Authority (EFSA). 2015. Scientific Opinion on the safety and efficacy of glycyrrhizic acid ammoniated (chemical group 30, miscellaneous substances) when used as a flavouring for all animal species. EFSA Journal, 13, 971.

13. European Union Regulation N. 834. 2007. Council Regulation (EC) No 834/2007 of 28 June 2007 on organic production and labelling of organic products and repealing Regulation (EEC) N. 2092/91. https://eur-lex.europa.eu/legalcontent/EN/TXT/PDF/? uri=CELEX:32007R0834\&from=EN (Accessed on 28 October 2020).

14. European Union Regulation N. 889. 2008. Commission Regulation (EC) No 889/2008 of 5 September 2008 laying down detailed rules for the implementation of Council Regulation (EC) No 834/2007 on organic production and labelling of organic products with regard to organic production, labelling and control. https://eur-lex.europa.eu/legal-content/EN/TXT/ PDF/?uri=CELEX:32008R0889\&from=EN (Accessed 28 October 2020).

15. Fiore C, Bordin L, Pellati D, Armanini D, Clari G. 2008. Effect of glycyrrhetinic acid on membrane band 3 in human erythrocytes. Archives of Biochemistry and Biophysics, 479, 46-51.

16. Fiore C, Eisenhut M, Krausse R, Ragazzi E, Pellati D, Armanini D, Bielenberg J. 2008. Antiviral effects of Glycyrrhiza species. Phytotherapy Research, 22, 141-148.

17. Fuji H-Y, Tian J, Luka C. 1986. Effect of glycyrrhetinic acid on influenza virus and pathogenic bacteria. Bulletin Chinese Mater Medical, 11, 238-241.

18. Gaudin E, Simon M, Quijada J, Schelcher F, Sutra J-F, Lespine A, Hoste H. 2016. Efficacy of sainfoin (Onobrychis viciifolia) pellets against multi resistant Haemonchus contortus and interaction with oral ivermectin: implications for on-farm control. Veterinary Parasitology, 227, 122-129. 
19. Giovanelli F, Mattellini M, Fichi G, Flamini G, Perrucci S. 2018. In vitro anthelmintic activity of four plant-derived compounds against sheep gastrointestinal nematodes. Veterinary Sciences, 5, 78.

20. Graebin C-S. 2018. The pharmacological activities of glycyrrhizinic acid ("Glycyrrhizin") and glycyrrhetinic acid. Sweeteners, 12, 245-261.

21. Guo N, Takechi M, Uno C. 1991. Protective effect of glycyrrhizin in mice with systemic Candida albicans infection and its mechanism. Journal of Pharmacy and Pharmacology, 13, 380-383.

22. Guo X, Cheng L, Liu J, Zhang S, Sun X, Al-Marashdeh O. 2019. Effects of licorice extract supplementation on feed intake, digestion, rumen function, blood indices and live weight gain of Karakul sheep. Animals, 9, 279.

23. Hazlett L-D, Ekanayaka S-A, McClellan S-A, Francis R. 2019. Glycyrrhizin use for multi-drug resistant Pseudomonas aeruginosa: in vitro and in vivo studies. Investigative Ophthalmology \& Visual Science, 60, 2978-2989.

24. Hoste H, Torres-Acosta J-F-J. 2011. Non chemical control of helminths in ruminants: adapting solutions for changing worms in a changing world. Veterinary Parasitology, 180, 144-154.

25. Hubert J, Kerboeuf D. 1992. A microlarval development assay for the detection of anthelmintic resistance in sheep nematodes. Veterinary Record, 130, 442-446.

26. Ifuku O. 2017. Chapter 20 - Botanical Ingredients, in Cosmetic Science and Technology: Theoretical Principles and Applications, 1st edn, Sakamoto K, Lochhead RY, Maibach HI, Yamashita Y, Editors. Elsevier: Amsterdam. p. 305-320.

27. Kalani K, Kushwaha V, Verma R, Murthy P-K, Srivastava S-K. 2013. Glycyrrhetinic acid and its analogs: a new class of antifilarial agents. Bioorganic \& Medicinal Chemistry Letters, 23, 2566-2570.

28. Karonen M, Ahern J-R, Legroux L, Suvanto J, Engström M-T, Sinkkonen J, Salminen J-P, Hoste H. 2020. Ellagitannins inhibit the exsheathment of Haemonchus contortus and Trichostrongylus colubriformis larvae: the efficiency increases together with the molecular size. Journal of Agricultural and Food Chemistry, $68,4176-4186$.

29. Kungumampriya D, Suresh B, Manoj Dhanraj K. 2018. Anthelmintic efficacy of Glycyrrhiza glabra on the nematode Haemonchus contortus - in vitro study. International Journal of Life Sciences Research, 6, 253-260.

30. Langer D, Czarczynska-Goslinska B, Goslinski T. 2016. Glycyrrhetinic acid and its derivatives in infectious diseases. Current Issues in Pharmacy and Medical Sciences, 29, 118-123.

31. Lee C-S, Kim Y-J, Lee M-S, Han E-S, Lee S-J. 2008. 18betaGlycyrrhetinic acid induces apoptotic cell death in SiHa cells and exhibits a synergistic effect against antibiotic anti-cancer drug toxicity. Life Sciences, 83, 481-489.

32. Li R-W, Li W, Sun J, Yu P, Baldwin R-L, Urban J-F. 2016. The effect of helminth infection on the microbial composition and structure of the caprine abomasal microbiome. Scientific Reports, 6, 20606.

33. Lima P-M-T, Crouzoulon P, Sanches T-P, Zabré G, Kabore A, Niderkorn V, Hoste H, Amarante A-F-T-D, Costa-Júnior L-M, Abdalla A-L, Louvandini H. 2019. Effects of Acacia mearnsii supplementation on nutrition, parasitological, blood parameters and methane emissions in Santa Inês sheep infected with Trichostrongylus colubriformis and Haemonchus contortus. Experimental Parasitology, 207, 107777.

34. Maestrini M, Tava A, Mancini S, Tedesco D, Perrucci S. 2020. In vitro anthelmintic activity of saponins from Medicago spp. against sheep gastrointestinal nematodes. Molecules, 25, 242.
35. MAFF - Ministry of Agriculture, Fisheries and Food. 1986. Manual of veterinary parasitological laboratory techniques. London, UK: Her Majesty's Stationary Office (HMSO), pp. $1-152$.

36. Martínez-Ortiz-de-Montellano C, Torres-Acosta J-F-J, Fourquaux I, Sandoval-Castro C-A, Hoste H. 2019. Ultrastructural study of adult Haemonchus contortus exposed to polyphenol-rich materials under in vivo conditions in goats. Parasite, 26, 65.

37. Morgan E-R, Aziz N-A, Blanchard A, Charlier J, Charvet C, Claerebout E, Geldhof P, Greer A-W, Hertzberg H, Hodgkinson J, Höglund J, Hoste H, Kaplan R-M, MartínezValladares M, Mitchell S, Ploeger H-W, Rinaldi L, von SamsonHimmelstjerna G, Sotiraki S, Schnyder M, Skuce P, Bartley D, Kenyon F, Thamsborg S-M, Vineer H-R, de Waal T, Williams A-R, van Wyk J-A, Vercruysse J. 2019. 100 questions in livestock helminthology research. Trends in Parasitology, 35, $52-71$.

38. Nielsen S-F, Chen M, Theander T-G, Kharazmi A, Christensen B. 1995. Synthesis of antiparasitic licorice chalcones. Bioorganic \& Medicinal Chemistry Letters, 5, 449-452.

39. Nowakowska Z. 2007. A review of anti-infective and antiinflammatory chalcones. European Journal of Medicinal Chemistry, 42, 125-137.

40. Omar H-R, Komarova I, El-Ghonemi M, Fathy A, Rashad R, Abdelmalak H-D, Yerramadha M-R, Ali Y, Helal E, Camporesi E-M. 2012. Licorice abuse: time to send a warning message. Therapeutic Advances in Endocrinology and Metabolism, 3, 125-138.

41. Pastorino G, Cornara L, Soares S, Rodrigues F. 2018. Liquorice (Glycyrrhiza glabra): a phytochemical and pharmacological review. Phytotherapy Reasearch, 32, 2323-2339.

42. Prichard R-K, Geary T-G. 2019. Perspectives on the utility of moxidectin for the control of parasitic nematodes in the face of developing anthelmintic resistance. International Journal for Parasitology: Drugs and Drug Resistance, 10, 69-83.

43. Ramünke S, Melville Rinaldi L, Hertzberg H, de Waal T, von Samson-Himmelstjerna G, Cringoli G, Mavrot F, Skuce P, Krücken J, Demeler J. 2016. Benzimidazole resistance survey for Haemonchus, Teladorsagia and Trichostrongylus in three European countries using pyrosequencing including the development of new assays for Trichostrongylus. International Journal for Parasitology: Drugs and Drug Resistance, 6, 230240.

44. Santos C, Campestrini L-H, Vieira D-L, Pritsch I, Yamassaki F-T, Zawadzki-Baggio S-F, Maurer J-B-B, Molento M-B. 2018. Chemical characterization of Opuntia ficus-indica (L.) Mill. hydroalcoholic extract and its efficiency against gastrointestinal nematodes of sheep. Veterinary Sciences, 5, 80.

45. Saratsi K, Hoste H, Voutzourakis N, Tzanidakis N, Stefanakis A, Thamsborg S-M, Mueller-Harvey I, Hadjigeorgiou I, Sotiraki S. 2020. Feeding of carob (Ceratonia siliqua) to sheep infected with gastrointestinal nematodes reduces faecal egg counts and worm fecundity. Veterinary Parasitology, 284, 109200.

46. Tatsuzaki J, Taniguchi M, Bastow KF, Nakagawa-Goto K, Morris-Natschke SL, Itokawa H, Baba K, Lee KH. 2007. Antitumor agents 255: novel glycyrrhetinic acid-dehydrozingerone conjugates as cytotoxic agents. Bioorganic \& Medicinal Chemistry, 15, 6193-9.

47. Taylor M-A, Coop R-L, Wall R-L. 2007. Veterinary Parasitology, 3rd edn. Oxford, UK: Blackwell Publishing Ltd.

48. Tryland I, Fiksdal L. 1998. Enzyme characteristics of $\beta$-Dgalactosidase- and $\beta$-D-glucuronidase-positive bacteria and their interference in rapid methods for detection of waterborne coliforms and Escherichia coli. Applied and Environmental Microbiology, 64, 1018-1023. 
49. van Wyk J-A, Mayhew E. 2013. Morphological identification of parasitic nematode infective larvae of small ruminants and cattle: a practical lab guide. Onderstepoort Journal of Veterinary Research, 80, 539.

50. Vercruysse J, Charlier J, Van Dijk J, Morgan E-R, Geary T, von Samson-Himmelstjerna G, Claerebout E. 2018. Control of helminth ruminant infections by 2030. Parasitology, 145, 414-415.

51. Villalba J-J, Miller J, Ungar E-D, Landau S-Y, Glendinning J. 2014. Ruminant self-medication against gastrointestinal nematodes: evidence, mechanism, and origins. Parasite, 21, 31.
52. Wei X, Zheng W, Tian P, Liu H, He Y, Peng M, Liu X, Li X. 2020. Administration of glycyrrhetinic acid reinforces therapeutic effects of mesenchymal stem cell-derived exosome against acute liver ischemia-reperfusion injury. Journal of Cellular and Molecular Medicine, 24, 11211-11220.

53. Xu CH, Wang P, Wang Y, Yang Y, Li DH, Li HF, Sun SQ, Wu XZ. 2013. Pharmacokinetic comparisons of two different combinations of Shaoyao-Gancao Decoction in rats: competing mechanisms between paeoniflorin and glycyrrhetinic acid. Journal of Ethnopharmacology, 149, 443-452.

Cite this article as: Maestrini M, Molento MB, Forzan M \& Perrucci S. 2021. In vitro anthelmintic activity of an aqueous extract of Glycyrrhiza glabra and of glycyrrhetinic acid against gastrointestinal nematodes of small ruminants. Parasite 28, 64 .

O PARASTE

An international open-access, peer-reviewed, online journal publishing high quality papers on all aspects of human and animal parasitology

Reviews, articles and short notes may be submitted. Fields include, but are not limited to: general, medical and veterinary parasitology; morphology, including ultrastructure; parasite systematics, including entomology, acarology, helminthology and protistology, and molecular analyses; molecular biology and biochemistry; immunology of parasitic diseases; host-parasite relationships; ecology and life history of parasites; epidemiology; therapeutics; new diagnostic tools.

All papers in Parasite are published in English. Manuscripts should have a broad interest and must not have been published or submitted elsewhere. No limit is imposed on the length of manuscripts.

Parasite (open-access) continues Parasite (print and online editions, 1994-2012) and Annales de Parasitologie Humaine et Comparée (1923-1993) and is the official journal of the Société Française de Parasitologie.
Submit your manuscript at http://parasite.edmgr.com/ 